\title{
Potensi Radikalisme di Perguruan Tinggi (Studi Kasus di Politeknik Negeri Balikpapan)
}

\author{
Basri $^{1^{*}, \text { Nawang Retno Dwiningrum }}{ }^{2}$ \\ ${ }^{I}$ Teknik Mesin Politeknik Negeri Balikpapan \\ ${ }^{2}$ Tata Boga Politeknik Negeri Balikpapan
}

\begin{abstract}
Unity is the mandate of the noble values of Pancasila as a legacy of the founders of Indonesia nation. Peace is an ideal set forth in the 1945 Constitution. Today the noble values of the Pancasila begin to fade because of the growth of fanatical attitudes towards certain groups, the emergence of various kinds of organizations with particular groups even in the name of Islam. Islam which teaches the values of glory such as; love of peace, love, mutual respect between one another religion, but religion is sometimes interpreted according to his will by certain groups as a foundation in launching his mission by approaching religious teachings by means of violence and coercion. Radicalism which was only directed at a less educated group of people, has now fallen to educated groups or students in universities. Some university leaders have indicated the involvement of students in radical understanding on campus. The purpose of this study is to further examine the potential of radicalism among Balikpapan State Polytechnic students, the object of this study is students especially students of internal organizational activists on campus or students of campus external organizational activists data collection techniques using questionnaires and interviews then the data is processed. The results of this study indicate the existence of radicalism among students. From data obtained, radicalism among students is not formed from internal campus but formed through the activities of external organizations that are outside the campus. The existence of student affiliations with external campus organizations forms students into radicals which then enter the campus.
\end{abstract}

Keywords : $\quad$ search radicalism, students

\begin{abstract}
Abstrak
Persatuan dan kesatuan adalah amanah dari nilai-nilai luhur pancasila sebagai warisan dari pendiri bangsa ini. Dewasa ini nilai-nilai luhur pancasila mulai pudar karena tumbuhnya sikap fanatik terhadap kelompok dan golongan tertentu, munculnya berbagai macam organisasi dengan mementingkan kelompok dan golongan tertentu bahkan hingga mengatasnamakan ajaran Islam. Agama Islam yang mengajarkan nilai-nilai kemuliaan seperti; cinta kedamaian, kasih sayang, saling menghormati antara satu dengan lainnya, tetapi agama terkadang ditafsirkan sesuai dengan kehendaknya oleh kelompok tertentu sebagai landasan dalam melancarkan misinya dengan pendekatan ajaran agama dengan cara kekerasan dan paksaan. Radikalisme atau paham radikal yang dulunya hanya diarahkan kepada kelompok masyarakat kurang terdidik, kini sudah meluas hingga kelompok terpelajar atau mahasiswa di perguruan tinggi. beberapa pimpinan perguruan tinggi sudah mengindikasikan adanya keterlibatan mahasiswa dalam pemahaman radikal di kampus. objek penelitian ini adalah mahasiswa yang ada di perguruan tinggi. Teknik pengumpulan data dengan menggunakan quesioner dan wawancara lalu datanya diolah. Hasil penelitian ini menunjukkan adanya potensi radikal di kalangan mahasiswa, terbentuk melalui aktifitas organisasi eksternal yang ada di luar kampus. Adanya interaksi mahasiswa dengan organisasi eksternal kampus berpotensi membentuk radikalisme mahasiswa dilingkungan kampus. Penelitian ini bertujuan untuk mengkaji lebih jauh adanya potensi mahasiswa yang memiliki paham radikal, dari hasil penelitian ini nantinya bisa dijadikan acuan maupun kebijakan dalam penguatan pembelajaran kewarganegaraan dan pendidikan agama Islam di Politeknik negeri Balikpapan
\end{abstract}

Kata kunci : menelusuri, mahasiswa, radikal 


\section{Pendahuluan}

Kampus memiliki peran strategis dalam pengembangan sumber daya manusia melalui tri dharma pendidikan tinggi yaitu penyelenggaraan pendidikan dan pengajaran, penelitian dan pengabdian kepada masyarakat. Selain fungsi tersebut kampus juga menjadi tempat bertemunya mahasiswa dengan beragam perbedaan, mulai dari suku, ras, hingga agama, beragam lintasan perbedaan tersebut berkumpul dalam satu wadah komunitas intelektual. Sehingga "Bhinneka Tunggal Ika" sangat terasa di kampus.

Dengan keragaman yang ada di kampus mahasiswa beserta seluruh civitas akademik memiliki tanggungjawab menjadi garda terdepan dalam menjaga dan mengawal ideologi serta menjaga persatuan bangsa. Peran kampus adalah mencetak para penerus bangsa, sehingga perannya begitu penting dalam kemajuan bangsa Indonesia. Mahasiswa sebagai bagian dari pemuda Indonesia merupakan aset berharga dari suatu bangsa.

Untuk memupuk keragaman menjadi kekuatan, bangsa Indonesia harus terus- menerus menanamkannya kepada generasi muda khususnya generasi milenial dan setelahnya. Dengan keragaman yang ada di Institusi pendidikan diharapkan mampu mencetak generasi masa depan Indonesia dengan menjadikan kampus sebagai pemersatu Bangsa. Karena hanya lewat lembaga pendidikan yang berkualitaslah keberagaman dalam berbangsa dapat ditanam lewat generasi muda yang berpendidikan.

Kehadiran mahasiswa di perguruan tinggi menjadi pertanda bahwa pendidikan tinggi masih dipandang sebagai salah satu lembaga penting dalam rangka melahirkan pemuda masa depan sesuai dengan bidang-bidang ilmu yang digelutinya, tidak ada harapan dari mereka, kecuali agar mampu memberikan kontribusi positif bagi keberlangsungan dunia pendidikan di kampusnya masing- masing, sekaligus dari mereka muncul komitmen untuk terus terlibat dalam perbaikan apapun di negeri ini.

Mahasiswa saat ini menghadapi sejumlah tantangan yang dapat mengancam keutuhan serta persatuan bangsa. Untuk itu sangat penting bagi para generasi muda khususnya mahasiswa untuk berperan memberikan sejumlah solusi terhadap masalah yang mengancam persatuan bangsa Indonesia. Kampus sebagai institusi pendidikan yang mencetak generasi masa depan pemersatu Bangsa. Karena hanya lewat lembaga pendidikan yang berkualitas keberagaman dalam berbangsa dapat ditanam lewat generasi muda yang berpendidikan.

Sumpah pemuda pada tahun 1928, proklamasi 1945, orde baru 1966, reformasi 1998, semua ini merupakan bukti sejarah kekuatan para pemuda Indonesia, yaitu mahasiswa sebagai tonggak perubahan kehidupan bangsa. Mahasiswa sebagai solusi permasalahan bangsa dan perubahan. Karena memang pada dasarnya peran mahasiswa adalah sebagai agen perubahan (agent of change). Sumber daya manusia terbesar dalam perubahan berada di tangan mahasiswa (pemuda), karena dari pemikiran-pemikirannya yang cerdas tidak mudah menyerah, dalam setiap langkah mahasiswa akan didasari dengan ketulusan dan keikhlasan dalam melakukan aktifitasnya.

Dewasa ini harapan itu mengalami beragam tantangan, khususnya berkaitan dengan perubahan cara berpikir mahasiswa yang berbeda bila dibandingkan ketika masih di tingkat Sekolah Menengah Atas. Dalam kondisi transisi pola pikir ini, mahasiswa mudah disusupi ideologi radikal/ ekstrimisme. Radikalisme yang dimaksud dalam kajian ini adalah gerakangerakan keagamaan yang bercita-cita ingin melakukan perubahan besar dalam politik kenegaraan dengan cara-cara kekerasan yang ingin mengubah bentuk negara kesatuan republik Indonesia menjadi negara Islam. oleh kelompok tertentu dengan ragam bentuknya, dengan pendekatan personal yang berisi ajakan penegakan Khilafah Islamiyah dan menolak sistem demokrasi yang dipandang sesat. 
Berbagai tindak kekerasan yang sering terjadi akibat fanatisme kelompok, golongan hingga mengatasnamakan agama pemahaman seperti ini merupakan sesuatu yang paradoks karena sesungguhnya agama mengajarkan nilai-nilai luhur tetapi sering kita menyaksikan kelompok-kelompok tertentu melakukan kerusakan dengan mengatasnamakan agama. Isu berkembangnya radikalisme yang mengkhawatirkan sudah meluas hingga masuk ke dunia kampus sehingga Mentri Riset Teknologi dan Pendidikan Tinggi Mohammad Nasir pada beberapa bulan yang lalu mengumpulkan pimpinan 3000 perguruan tinggi negeri dan mendeklarasikan melawan paham radikal di Perguruan Tinggi. Berdasarkan uraian tersebut penulis ingin mengkaji lebih jauh radikalisme atau paham radikal di perguruan tinggi, khususnya di Politeknik Negeri Balikpapan.

Hasil penelitian ini akan menguatkan penelitian-penelitian sebelumnya (Saifuddin, 2011) bahwa penyebaran radikalisme sasarannya bukan hanya masyarakat biasa tetapi juga kepada mahasiswa perguruan tinggi umum dengan alasan perguruan tinggi umum lebih mudah menjadi target radikal karena mahasiswa yang ada di PTUN umumnya berasal dari SMU/SMK yang pemahaman agamanya rendah, sementara dari perguruan tinggi keagamaan mahasiswanya berasal dari sekolah yang berbasis keagamaan yang pemahaman keagamaannya sudah kuat sehingga tidak mudah didoktrinasi oleh paham radikal. Lebih jauh Saifuddin (2011) mengakui bahwa paham radikal juga sudah meluas hingga ke perguruan tinggi keagamaan belakangan ini sejak adanya perubahan perguruan tinggi keagamaan dari IAIN menjadi universitas (UIN) sehingga lulusan SLTA dari sekolah manapun bisa melanjutkan di UIN. Sedangkan penelitian Angga Dwi (2010) lebih menekankan kepada upaya-upaya pencegahan berkembangnya paham radikal diperguruan tinggi dengan mengoptimalkan seluruh organisasi kemahasiswaan dalam melakukan kegitan dan pembinaan kepada mahasiswa.

Penelitian ini bertujuan untuk mengkaji lebih jauh adanya potensi mahasiswa yang memiliki paham radikal, dari hasil penelitian ini nantinya bisa dijadikan acuan maupun kebijakan dalam penguatan pembelajaran kewarganegaraan dan pendidikan agama Islam di Politeknik Negeri Balikpapan.

\section{Metodologi}

Penelitian ini menggunakan pendekatan kualitatif. Penelitian kualitatif merupakan penelitian yang menghadirkan data deskriftif beberapa kata tertulis atau lisan dari orang-orang atau pelaku yang dapat diamati (Moelong, 2012). Karena data yang ingin diungkap dalam kajian ini adalah masalah sosial maka penulis menggunakan pendekatan penelitian kualitatif yang bertujuan untuk memudahkan peneliti karena ikut terlibat langsung selain itu data sosial sulit dipastikan kebenarannya maka dengan pengumpulan data secara triangulasi (gabungan) Untuk memahami interkasi sosial yang komplek hanya dapat diurai dengan melakukan penelitian dengan metode kualitatif dengan teknik pengumpulan data dengan menggunakan kuesioner dan wawancara mendalam (Sugiono, 2010).

Adapun responden dalam penelitian ini adalah mahasiswa dari 4 jurusan dengan pertimbangan tertentu, seperti waktu, tenaga dan biaya. Ditentukan sampel 90 mahasiswa dari 4 jurusan. Wawancara dilakukan secara sampling kepada mahasiswa yang aktif berorganisasi dengan teknik analisis data Model Miles Huberman (Sugiono, 2010) sebagai berikut: 


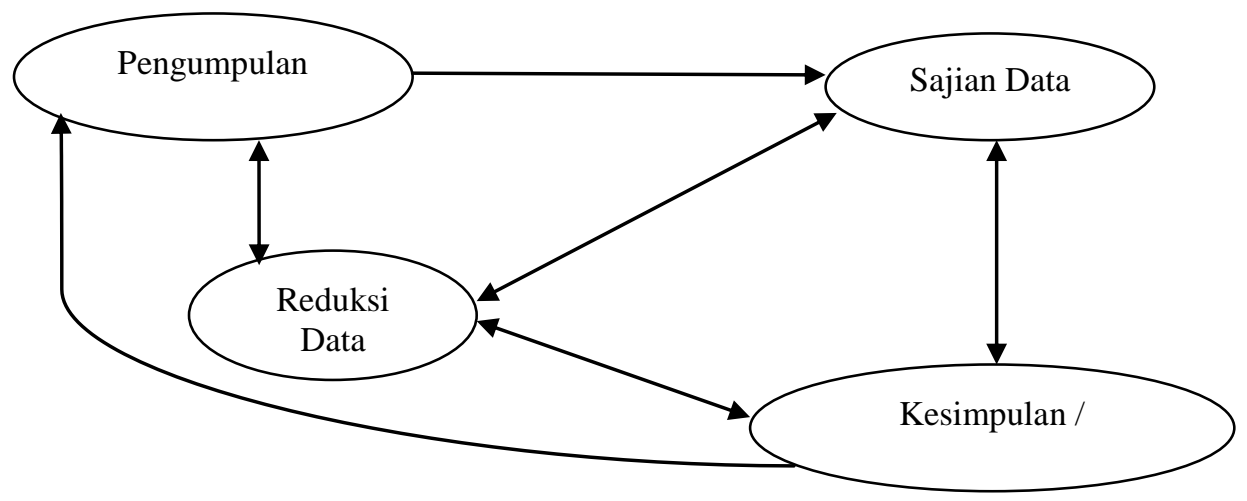

Gambar 1 Teknik Analisis Data

Langkah-langkah yang digunakan dalam penelitan ini adalah sebagai berikut



Gambar 2 Langkah- langkah penelitian

Langkah-langkah yang digunakan dalam penelitian seperti pada Gambar 2 dengan mengacu kepada tiga langkah penelitian tersebut diatas yang dijabarkan sebagai adalah sebagai berikut :

1. Menentukan masalah yang ingin diteliti

2. Mengumpulkan bahan yang relevan dari berbagai referensi yang berhubungan dengan masalah yang diteliti yaitu yang berhubungan dengan sebab munculnya radikalisme di kalangan mahasiswa diperguruan tinggi.

3. Menentukan strategi dengan menyusun instrumen berupa quesioner dan panduan atau daftar pertanyaan utama yang akan

digunakan dalam menggali informasi dari informan yang terkait terbentuknya radikalisme dikalangan mahasiswa serta strategi pengisian kuesioner dan penentuan mahasiswa yang akan diwawancara.

4. Mengumpulkan data dari quesioner yang diberikan kepada mahasiswa dan dari hasil wawancara. Dalam penelitian penulis menggunakan wawancara terbuka yaitu peneliti memberikan kebebasan diri dan mendorong kepada informan untuk berbicara secara luas terbuka dan mendalam. Dari data yang diperoleh dari quesioner dan catatan pada saat wawancara kemudian dikalsifikasikan mana data yang sesuai dan yang tidak sesuai untuk persiapan pengolah data.

5. Dari data-data yang diperoleh yang di klasifikasi,diolah lalu ditafsirkan. 
6. Dari hasil penafsiran data dari masing-masing pertanyaan yang ada dalam kuesioner maupun informasi saat wawancara berlangsung yang ditulis dalam catatan kemudian ditulis dalam laporan hasil penelitian.

\section{Hasil dan Pembahasan}

Tumbuh dan berkembangnya paham radikal dikalangan mahasiswa di Perguruan tinggi tidak terlepas dari konstribusi dan peran aktif mahasiswa itu sendiri sejak masih duduk dibangku pendidikan sebelumnya, baik di sekolah lanjutan tingkat pertama (SLTP) maupun di Sekolah lanjutan tingkat atas (SLTA). Bagi mahasiswa yang aktif mengikuti kegiatan organisasi ekternal atau berorganisasi di luar sekolah/ kampus ada kecenderungan mahasiswa tersebut memiliki cara pandang yang ekstrim atau fanatik terhadap paham dari organisasi yang diikuti dibandingkan dengan mahasiswa yang hanya akif berorganisasi di internal sekolah. Analisis ini didukung oleh kajian yang dilakukan oleh Saifuddin (2012), dari hasil kajiannya menjelaskan munculnya radikalisme dikalangan mahasiswa bukan sesuatu yang muncul sendiri ditengah-tengah kampus, radikalisme itu muncul karena adanya proses komunikasi dengan jaringa-jaringan organisasi radikal di luar.

Data penelitian diambil menggunakan kuesioner dan wawancara terhadap mahasiswa yang pada umumnya aktif berorganisasi sebelum masuk ke Perguruan tinggi. Organisasi yang diikuti mahasiswa sangat bervariasi sesuai dengan bakat dan minat dan potensi diri mahasiswa, baik yang bersifat kepemimpinan, olah raga, bahasa, seni dan yang bersifat keagamaan maupun gerakan/politik. Diantara organisasi yang diikuti mahasiswa sebelum masuk ke Perguruan tinggi seperti yang terlihat dalam grafik yang tersaji dalam grafik berikut :

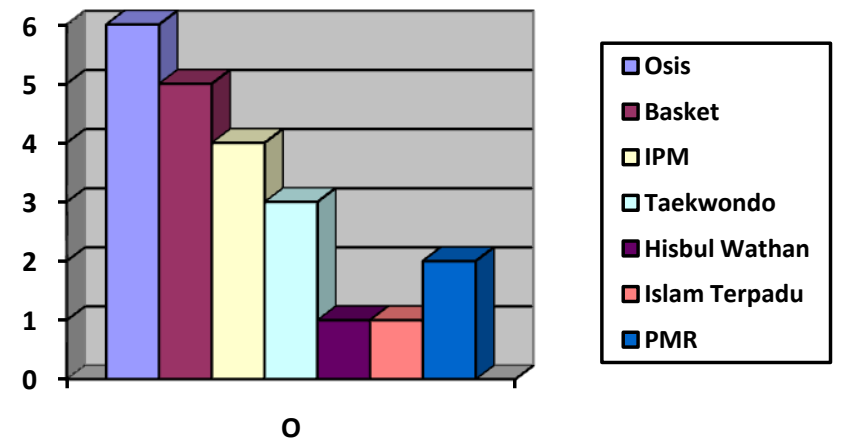

Gambar 3 Latar Belakang Organisasi yang Pernah diikuti Mahasiswa Poltekba

Gambar 3 menunjukkan bahwa mahasiswa yang kuliah di Politeknik Negeri Balikpapan sejak masih dibangku pendidikan sekolah menengah atas sudah aktif mengikuti organisasi, baik organisasi internal kampus seperti Organisasi Siswa Intra Sekolah (OSIS), Pramuka, Palang Merah Remaja (PMR), Paduan suara, Latihan Baris Berbaris, Softball Club, Taekwondo Club Quba, Stekpala, Islam terpadu, maupun organisasi eksternal kampus. Ikatan Pemuda Muhammadiyah (IPM) dan Hizbul Wathan, hingga menjadi mahasiswa masih tetap eksis berorganisasi untuk mengembangkan potensi dirinya, baik organisasi internal kampus seperti, Student English Club (SEC), Majelis Permusyawaratan Mahasiswa (MPM), KPIS, Himpunan Mahasiswa Jurusan (HMJ), GEMA, dan Himpunan Mahasiswa Pecinta Alam (HIMPA) maupun organisasi eksternal kampus seperti Himpunan Mahasiswa Islam (HMI) Hizbut Tahrir Indonesia (HTI) Ikatan Mahasiswa Muhammadiyah (IMM) Hizbul Wathan (HW) Pencak Silat, Kesatuan Aksi Mahasiswa Muslim Indonesia (KAMMI), Peregerakan Mahasiswa Islam Indonesia (PMI). Seperti yang terlihat pada grafik berikut : 

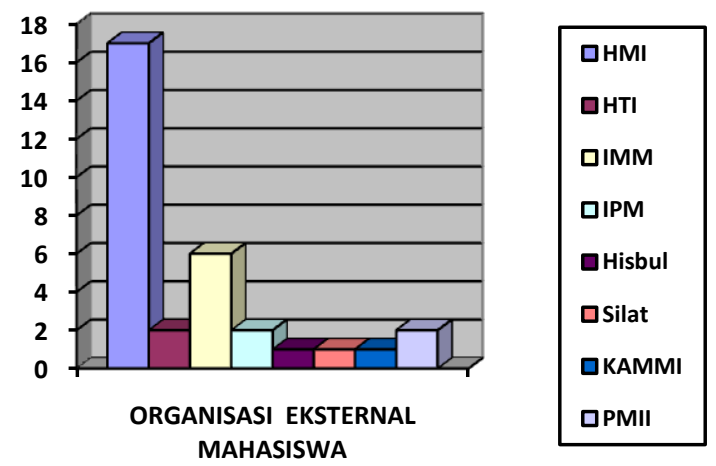

Gambar 4 Keterlibatan Mahasiswa Poltekba dalam Organisasi Eksternal

Dari 380 mahasiswa yang dijadikan sampel diketahui 8,4 persen (32 mahasiswa) yang aktif mengikuti organisasi di luar kampus dan 12,36 \% (42 mahasiswa) yang hanya aktif mengikuti organisasi internal kampus dan tidak aktif berorganisasi di luar kampus secara umum 7,89 \% (30 mahasiswa ) yang aktif di dalam kampus dia juga aktif berorganisasi di luar kampus ini menunjukkan mahasiswa Poltekba yang aktif mengembangkan potensi dirinya bukan hanya aktif di organisasi internal kampus tetapi juga aktif berorganisasi eksternal di luar kampus. Dari 380 mahasisawa ada 4 mahasiswa (1,04\%) yang terindikasi paham radikal berdasarkan indikator dari Badan Nasional Penanggulangan Teroris (BNPT) yaitu; ingin melakukan perubahan dengan cepat menggunakan kekerasan mengatasnamakan agama, mengkafirkan orang lain, memaknai jihad secara terbatas, mendukung, menyebarkan dan mengajak bergabung dengan ISIS. Dari hasil analisis angket dan wawancara terhadap responden seperti ; sangat setuju ingin mengubah ideologi negara yang berdasarkan pancasila dan mengganti dengan negara khilafah, setuju melakukan kekerasan bagi orang lain yang tidak sependapat dengan keyakinannya, bahkan dia rela mati untuk mempertahankan keinginan karena dianggap jihad, tidak menyetujui pemimpin yang berbeda keyakinan. Tiga dari empat kriteria radikal dari BNPT, sudah terdapat pada 4 mahasiswa tersebut. Dari hasil analisis ini juga diketahui terbentuknya paham radikal dikalangan mahasiswa melalui jaringan organisasi eksternal kampus.

Yusuf Qordowi dalam Hammad (2018) menyebut kriteria radikal adalah (1) sering mengklaim kebenaran tunggal dan menyesatkan kelompok lain yang tidak sependapat dengan isi pikirannya; (2) mempersulit agama Islam yang ringan dengan berargumen bahwa ibadah sunah seakan-akan wajib dan makruh seakan-akan haram; (3) mayoritas kelompok radikal sangat berlebihan dalam beragama yang tidak pada tempatnya; (4) dalam menjalin interaksi sosial cenderung kasar keras dalam bicara da bersikap emosional dalam berdakwah; (5) mudah berburuk sangka kepada orang lain di luar golongannya; (5) mudah mengkafirkan orang lain yang berbeda pendapat.

Ada dua organisasi eksternal yang berkembang di kampus Politeknik negeri Balikpapan yaitu Himpunan Mahasiswa Islam dan Ikatan Mahasiswa Muhammadiyah/Ikatan pemuda Muhammadiyah. Kedua organisasi ini lebih berkembang di Politeknik karena memiliki kader/anggota dan komisariat/cabang sedangkan organisasi ekternal yang lain anggota/kadernya kurang berkembang meskipun memiliki kader hanya satu atau dua orang. Berdasarkan data yang diperoleh, mahasiswa yang hanya aktif di kampus yang hanya mengikuti organisasi internal kampus kecenderungan tidak memiliki pola fikir yang radikal, seperti; sangat menghargai dengan pemeluk agama lain, dan menjunjung tinggi pemimpin meskipun pemimpin itu berbeda keyakinan atau non muslim, mengakui ideologi pancasila sebagai dasar negara republik 
Indonesia, menghindari sikap kekerasan dan arogansi dalam melakukan tindakan sekalipun itu dengan keyakinan yang berbeda.

Menurut Azra (2003) munculnya kelompok radikal di Indonesia diakibatkan oleh disamping euforia demokrasi, juga karena dicabutnya undang-undang anti-subversi oleh Presiden Habibie yang pada gilirannya memberikan ruang yang lebar bagi kelompok ekstrimis untuk mengekspresikan gagasan dan aktifitas mereka. Abuza (2007) juga mengatakan bahwa jatuhnya rezim otoriter Soeharto memicu lahirnya kekuatan civil society secara masif yang pada gilirannya memberikan ruang kepada kelompok tertentu termasuk di dalamnya kelompok radikal (uncivil) yang mengekspresikan kepentingannya dengan cara menebarkan kebencian dan intoleransi dengan menggunakan cara-cara kekerasan (violence). Reformasi melahirkan banyak gerakan keagamaan termasuk kelompok islam militan (islam radikal) yang mengkonsolidasikan diri dan menyerukan diberlakukannya syari'ah islam. Beberapa organisasi yang termasuk dalam kelompok ini adalah Front Pembela Islam (FPI), Hizbut Tahrir Indonesia (HTI), Laskar Jihad (LJ), Majelis Mujahidin Indonesia (MMI), dan Jamaah Islamiyah (JI). Anshori (2011) menjelaskan organisasi FPI, HTI, MMJ, dan LJ muncul seperti jamur untuk mewujudkan citacitanya. Abuza (2007) membagi empat kategori dalam kelompok ini. Pertama adalah muslim militan (laskar) yang melancarkan aksinya dengan kekerasan (violence), akan tetapi hanya dalam batas tertentu. Mereka ini disebut juga sebagai "reactive jihadists" yang mana kekerasan digunakan untuk merespon situasi atau kejadian tertentu. Kedua adalah kelompok militan "Islamis", yang mana gerakannya tersporadis, cenderung menggunakan kekerasan, serta pengetahuan dan interpretasi kelompok ini terhadap nilai-nilai islam sangat literal (rudimentary). Ketiga adalah kelompok yang terdiri dari mahasiswa radikal atau kelompok berbasis kampus (university-based organizations). Kelompok ini sangat anti terhadap barat yang mana para pengikutnya cenderung simpatik terhadap penyebab-penyebab yang lebih radikal.

Aspihanto (2017) mengemukakan bahwa upaya untuk mencengah berkembangnya paham radikal adalah dengan melakukakan tindakan preventif dengan melibatkan pihak-pihak yang berwenang seperti :

1. Peran pemerintah yaitu dengan adanya kebijakan dalam mengurangi eksterisme dengan adanya undang-undang anti terorisme,

2. Institusi keagamaan dan sekolah agama melalui materi pembelajaran keagamaan yang mengutamakan gagasan Islam yang rahmatan lil alamin dan seperti yang disampaikan

Sedangkan diperguruan tinggi upaya pencegahan paham radikal dikalangan mahasiswa dengan melakukan upaya-upaya sebagai berikut.

1. Memperkuat dalam menanamkan nilai-nilai Pancasila kepada mahasiswa, dengan menanamkan nilai-nilai Pancasila agar bisa mencegah adanya faham radikal agar mahasiswa tidak terjerumus dalam aksi kekerasan seperti terorisme ., melalui penanaman nilai-nilai Pancasila diharapkan masyarakat kembali kepada jati diri bangsa Indonesia , masyarakat yang berkeTuhanan, berperikemanusiaan, berpersatuan , berkerakyatan dan berkeadilan.

2. Memperkuat dan membina organisasi kemahasiswaan, yang bisa menjadi wadah bagi mahasiswa untuk berorganisasi dan menyalurkan bakatnya, sehingga mahasiswa tidak mencari organisasi di luar yang mengajarkan pemahaman yang salah.

3. Dalam pendidikan agama Islam mahasiswa diberi pencerahan tentang konsep jihad yang benar, sehingga tidak mudah diindoktrinasi oleh suatu organisasi tentang pemahaman jihad yang melenceng dari ajaran agama. 


\section{Kesimpulan}

Berdasarkan hasil analisis data dapat disimpulkan ada potensi radikalisme di kalangan mahasiswa Politeknik Negeri Balikpaan meski masih tergolong rendah. Terbentuknya paham radikal dikalangan mahasiswa sangat dipengaruhi oleh interaksi dengan jaringan organisasi yang ada di luar kampus yang menganut paham radikal.

\section{Saran}

Agar penelitian menjadi lebih baik dan mendalam, di masa yang akan datang bisa dilakukan penelitian lanjutan dengan melibatkan lebih banyak mahasiswa sebagai responden atau informan. Dan langkah-langkah untuk mengantisipasi munculnya paham radikal di kalangan mahasiswa bisa segera diambil oleh institusi Politeknik negeri Balikpapan.

\section{Ucapan Terima Kasih}

Dengan selesainya penelitian ini penulis mengucapkan terima kasih kepada mahasiswa Teknik Mesin, Tata Boga dan Perbankan dan Keuangan khususnya kepada mahasiswa aktifis internal kampus maupun mahasiswa aktifis eksternal kampus yang telah bersedia memberikan data terkait dengan penelitian ini. Demikan juga kepada Pusat Penelitian dan Pengabdian kepada Masyarakat (P3M) Poltekba yang telah memfasilitasi pendanaan sehingga penelitian ini dapat terlaksana dengan baik, dan kepada semua pihak yang telah mendukung terlaksananya penelitian ini. Semoga hasil penelitian ini dapat memberikan manfaat untuk pengembangan kajian ilmuilmu sosial.

\section{Daftar Pustaka}

Azra, Azyumardi. 2003. "Bali and Southeast Asian Islam: debunking the myths". In After Bali: The Threat of Terrorism in Southeast Asia, Edited by: Ramakrishna, Kumar and Tan, Seng. 39-57. Singapore: World Scientific and Institute of Defence and Strategic Studies.

Asrori, Ahmad.2015. "Radikalisme di Indonesia: Antara Historisitas dan Antropisitas". Jurnal Kalam IAIN Intan Lampung Volume 9 No.2. 2015, 254- 259. https://doi.org/10.24042/klm.v9i2.331

Aspihanto, Aan dan Muin, F.2017. "Sinergi Terhadap Pencegahan Terorisme". Prosiding Seminar Nasional Hukum Universitas Negeri Semarang, Volume 3 no. 1, 2017, 73-90

Dwi Larasati, Angga.2018. "Peranan Lembaga Kemahasiswaan dalam Menangkal Radikalisme di Universitas Lampung". Skripsi: Universitas Lampung

Mohammad al Hammad, Ahmad..2018. "Radikalisme di Kalangan Mahasiswa Surabaya(Studikasus Kreteria Radikalisme Menurutyusuf Al-Qardhawi)”. Skripsi: Universitas Islam Negeri Sunan Ampel

Moloeng, Lexy. 2012. "Metodologi Penelitian Kualitatif Edisi Revisi”. Bandung: PT Remaja Rosdakarya. Sugiyono.2010. "Metode Penelitian Kuantitatif dan Kualitatif dan R\&D”. Alfabeta: Bandung Suharsimi Arikunto.2010. "Prosedur Penelitian Suatu Pendekatan Praktik". Jakarta: PT Rineka Cipta Saifuddin.2011."Radikalisme Islam di Kalangan Mahasiswa. Analisis: Jurnal Studi Keislaman”. Volume 11, No 1 2011. https://doi.org/10.42042/analisis.v11i1.605

Zachary, Abuza.2006.”Political Islam and violence in Indonesia". Routledge:London https://doi.org/10.4324/9780203969250 